\title{
Front Matter: Volume 7472
}

, "Front Matter: Volume 7472," Proc. SPIE 7472, Remote Sensing for Agriculture, Ecosystems, and Hydrology XI, 747201 (6 October 2009); doi: 10.1117/12.848121

SPIE. Event: SPIE Remote Sensing, 2009, Berlin, Germany 


\section{PROCEEDINGS OF SPIE}

\section{Remote Sensing for Agriculture, Ecosystems, and Hydrology XI}

Christopher M. U. Neale Antonino Maltese

Editors

1-3 September 2009

Berlin, Germany

Sponsored by

SPIE Europe

Cooperating Organisations

SPIE

EARSC-European Association of Remote Sensing Companies

EOS-European Optical Society

RSPSOC-Remote Sensing and Photogrammetry Society (United Kingdom)

German Society for Photogrammetry, Remote Sensing, and Geoinformation eV (Germany)

Published by

SPIE

Volume 7472

Proceedings of SPIE, 0277-786X, v. 7472 
The papers included in this volume were part of the technical conference cited on the cover and title page. Papers were selected and subject to review by the editors and conference program committee. Some conference presentations may not be available for publication. The papers published in these proceedings reflect the work and thoughts of the authors and are published herein as submitted. The publisher is not responsible for the validity of the information or for any outcomes resulting from reliance thereon.

Please use the following format to cite material from this book:

Author(s), "Title of Paper," in Remote Sensing for Agriculture, Ecosystems, and Hydrology XI, edited by Christopher M. U. Neale, Antonino Maltese, Proceedings of SPIE Vol. 7472 (SPIE, Bellingham, WA, 2009) Article CID Number.

ISSN 0277-786X

ISBN 9780819477774

Published by

SPIE

P.O. Box 10, Bellingham, Washington 98227-0010 USA

Telephone +1 3606763290 (Pacific Time) · Fax +1 3606471445

SPIE.org

Copyright (C) 2009, Society of Photo-Optical Instrumentation Engineers

Copying of material in this book for internal or personal use, or for the internal or personal use of specific clients, beyond the fair use provisions granted by the U.S. Copyright Law is authorized by SPIE subject to payment of copying fees. The Transactional Reporting Service base fee for this volume is $\$ 18.00$ per article (or portion thereof), which should be paid directly to the Copyright Clearance Center (CCC), 222 Rosewood Drive, Danvers, MA 01923. Payment may also be made electronically through CCC Online at copyright.com. Other copying for republication, resale, advertising or promotion, or any form of systematic or multiple reproduction of any material in this book is prohibited except with permission in writing from the publisher. The CCC fee code is 0277-786X/09/ $\$ 18.00$.

Printed in the United States of America.

Publication of record for individual papers is online in the SPIE Digital Library.

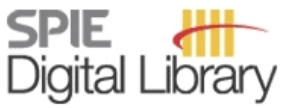

SPIEDigitalLibrary.org

Paper Numbering: Proceedings of SPIE follow an e-First publication model, with papers published first online and then in print and on CD-ROM. Papers are published as they are submitted and meet publication criteria. A unique, consistent, permanent citation identifier (CID) number is assigned to each article at the time of the first publication. Utilization of CIDs allows articles to be fully citable as soon they are published online, and connects the same identifier to all online, print, and electronic versions of the publication. SPIE uses a six-digit CID article numbering system in which:

- The first four digits correspond to the SPIE volume number.

- The last two digits indicate publication order within the volume using a Base 36 numbering system employing both numerals and letters. These two-number sets start with 00, 01, 02, 03, 04, $05,06,07,08,09,0 A, 0 B \ldots 0 Z$, followed by 10-1Z, 20-2Z, etc.

The CID number appears on each page of the manuscript. The complete citation is used on the first page, and an abbreviated version on subsequent pages. Numbers in the index correspond to the last two digits of the six-digit CID number. 


\section{Contents}

$\begin{array}{ll}\text { ix } & \text { Conference Committee } \\ \text { xi Introduction }\end{array}$

\section{SESSION 1 HYDROLOGICAL AND ECOSYSTEM MODELING}

747203 Tidal flood monitoring in marsh estuary areas from Landsat TM data [7472-02]

M. J. Polo, J. Regodón, Univ. of Cordoba (Spain); M. P. González-Dugo, Andalusian Institute of Agricultural and Fishery Formation (Spain)

747204 Testing the performance of the MNDVI vegetation index [7472-03]

G. A. Skianis, D. A. Vaiopoulos, Univ. of Athens (Greece); K. G. Nikolakopoulos, Institute of Geology \& Mineral Exploration (Greece)

747205 Hydrological impacts of land cover change in the Dragonja catchment (Slovenia) [7472-04] H. Beck, G. Salvini, Vrije Univ. Amsterdam (Netherlands); J. Schellekens, Deltares (Netherlands); S. Bruijnzeel, R. de Jeu, Vrije Univ. Amsterdam (Netherlands)

747206 Modelling the stream flow change in a poorly gauged mountainous watershed, southern Tianshan Mountain, using multi-source remote sensing data [7472-05]

Z. Sun, Nanjing Institute of Geography and Limnology (China); C. Opp, T. Hennig, Univ. Marburg (Germany)

\section{SESSION 2 LAND USE AND CHANGE DETECTION}

747207 Estimation of inter-annual winter crop area variation and spatial distribution with low resolution NDVI data by using neural networks trained on high resolution images [7472-06] C. Atzberger, F. Rembold, European Commission Joint Research Ctr. (Italy)

747208 Storm damage assessment support service in the U.S. corn belt using RapidEye satellite imagery [7472-08] M. A. Capellades, S. Reigber, M. Kunze, RapidEye AG (Germany)

747209 Vegetation cover change detection in Chamela-Cuixamala, Mexico [7472-09] B. De la Barreda Bautista, A. A. López-Caloca, Ctr. de Investigación en Geografía y Geomática, Ing. Jorge L. Tamayo (Mexico)

74720 A Monitoring the urban expansion of Thrakomakedones area (North- Western Athens) due to the Olympic Games using high resolution satellite data and GIS techniques [7472-10] K. G. Nikolakopoulos, P. I. Tsombos, G. Papanikolaou, Institute of Geology \& Mineral Exploration (Greece)

$7472 \mathrm{OB} \quad$ Using neural networks to map Africa's land cover with Landsat ETM+ SLC-off imagery [7472-11]

M. J. Aitkenhead, Univ. of Aberdeen (United Kingdom) 
7472 OC Multitemporal burnt area detection methods based on a couple of images acquired after the fire event [7472-90]

R. Carlà, L. Santurri, National Research Council, Institute Applied Physics N. Carrara, CNR (Italy); L. Bonora, C. Conese, National Research Council, Institute of Biometerology, CNR (ltaly)

\section{SESSION $3 \quad$ IRRIGATION WATER MANAGEMENT}

7472 OD Earth observation products for operational irrigation management: the PLEIADeS project [7472-12]

G. D'Urso, Univ. of Naples Federico II (Italy); F. Vuolo, Univ. of Southampton (United Kingdom); K. Richter, Univ. of Naples Federico II (Italy); A. Calera Belmonte, M. A. Osann, Univ. de Castilla-La Mancha (Spain)

$74720 \mathrm{E}$ Irrigation water use monitoring at watershed scale using series of high-resolution satellite images [7472-13]

A. Díaz, M. P. González-Dugo, IFAPA (Spain); S. Escuin, Empresa pública para el Desarrollo Agrario y Pesquero (Spain); L. Mateos, Instituto de Agricultura Sostenible (Spain); F. Cano, Empresa pública para el Desarrollo Agrario y Pesquero (Spain); V. Cifuentes,

Confederación Hidrográfica del Guadalquivir (Spain); J. L. Tirado, N. Oyonarte, Empresa pública para el Desarrollo Agrario y Pesquero (Spain)

7472 OF Integration of wireless sensor network and remote sensing for monitoring and determining irrigation demand in Cyprus [7472-14]

A. Agapiou, Cyprus Univ. of Technology (Cyprus); G. Papadavid, Cyprus Univ. of Technology (Cyprus) and Agricultural Research Institute of Cyprus (Cyprus); D. G. Hadjimitsis, Cyprus Univ. of Technology (Cyprus)

\section{SESSION 4 ESTIMATION OF VEGETATION PARAMETERS}

$7472 \mathrm{OH} \quad$ Reflectance modeling of vineyards under water stress based on the coupling between 3D architecture and water balance model [7472-17]

R. López-Lozano, F. Baret, UMR EMMAH, INRA (France); I. García de Cortázar Atauri, UMR Agroclim, INRA (France); B. Tisseyre, UMR ITAP, Montpellier (France); E. Lebon, UMR LEPSE, INRA (France)

\section{SESSION 5 FORESTRY AND COASTAL APPLICATIONS}

$7472 \mathrm{OL} \quad$ Remote sensing analysis of forest vegetation changes due to climate and anthropogenic impacts [7472-21]

M. A. Zoran, National Institute of Research and Development for Optoelectronics (Romania); L. F. V. Zoran, Univ. Politechnica of Bucharest (Romania); A. I. Dida, ROMSILVA (Romania)

747200 Coralline reefs classification in Banco Chinchorro, Mexico [7472-24]

A. I. Contreras-Silva, A. A. López-Caloca, Ctr. de Investigación en Geografía y Geomática, Ing. Jorge L. Tamayo (Mexico) 
7472 OP Integration of micro-sensor technology and remote sensing for monitoring coastal water quality in a municipal beach and other areas in Cyprus [7472-25]

D. G. Hadjimitsis, Cyprus Univ. of Technology (Cyprus); M. G. Hadjimitsis, Cyprus Univ. of Technology (Cyprus) and Municipality of Paphos-Cyprus (Cyprus); K. Themistocleous,

A. Agapiou, Cyprus Univ. of Technology (Cyprus)

\section{SESSION $6 \quad$ LIDAR AND RADAR APPLICATIONS IN HYDROLOGY}

7472 OR Towards the development of a 30 year record of remotely sensed vegetation optical depth [7472-28]

R. A. M. de Jeu, Vrije Univ. Amsterdam (Netherlands); T. R. H. Holmes, USDA Hydrology and Remote Sensing Lab. (United States); G. van der Werf, Vrije Univ. Amsterdam (Netherlands)

7472 OS Sensitivity analysis on the relationship between vegetation growth and multi-polarized radar data [7472-29]

F. Capodici, G. La Loggia, Univ. degli Studi di Palermo (Italy); G. D'Urso, Univ. degli Studi di Napoli Federico II (Italy); A. Maltese, G. Ciraolo, Univ. degli Studi di Palermo (Italy)

7472 OU Algorithm development for snow density estimation using polarimetric advanced SAR data [7472-31]

G. Singh, G. Venkataraman, Indian Institute of Technology, Bombay (India)

\section{SESSION 7 THERMAL INFRARED REMOTE SENSING}

7472 OW Spatial distribution of soil water content from airborne thermal and optical remote sensing data [7472-33]

K. Richter, M. Palladino, Univ. of Naples Federico II (Italy); F. Vuolo, Ariespace s.r.l. (Italy);

L. Dini, ASI (Italy); G. D'Urso, Univ. of Naples Federico II (Italy)

7472 OY Comparison of three methods based on the temperature-NDVI diagram for soil moisture characterization [7472-35]

J.-C. Krapez, ONERA, DOTA (France); A. Olioso, INRA, CSE (France); B. Coudert, CESBIO, IUT-A (France)

$7472 \mathrm{OZ}$ The effect of mesoscale mountains on precipitation horizontal and vertical distribution over South China [7472-36]

S. Zhu, H. Xu, Nanjing Univ. of Information Science and Technology (China)

747210 Monitoring geothermal activity in Yellowstone National Park using airborne thermal infrared remote sensing [7472-37]

C. M. U. Neale, S. Sivarajan, Utah State Univ. (United States); O. Z. Akasheh, University of Nebraska-Lincoln (United States); C. Jaworowski, H. Heasler, Yellowstone Ctr. For Resources (United States) 
747212 Comparison between energy balance and mass balance models for actual evapotranspiration assessment [7472-39]

A. Gentile, Univ. of Palermo (Italy); L. Pierce, California State Univ., Monterey Bay (United States); G. Ciraolo, Univ. of Palermo (Italy); G. Zhang, Utah State Univ. (United States);

G. La Loggia, Univ. of Palermo (Italy); R. Nemani, NASA Ames Research Ctr. (United States)

747213 Effects of rainfall events on the evapotranspiration retrieved by an energy balance model [7472-40]

A. Maltese, C. Cammalleri, G. Ciraolo, G. La Loggia, Univ. degli Studi di Palermo (Italy)

\section{SESSION 9 VEGETATION AND CROP MONITORING I}

747215 Spectral signature measurements during the whole life cycle of annual crops and sustainable irrigation management over Cyprus using remote sensing and spectro-radiometric data: the cases of spring potatoes and peas [7472-42]

G. Papadavid, Cyprus Univ. of Technology (Cyprus) and Agricultural Research Institute of Cyprus (Cyprus); D. G. Hadjimitsis, Cyprus Univ. of Technology (Cyprus)

747217 Identification of combined vegetation indices for the early detection of plant diseases [7472-44]

T. Rumpf, A. Mahlein, D. Dörschlag, L. Plümer, Univ. of Bonn (Germany)

\section{SESSION 10 VEGETATION AND CROP MONITORING II}

74721 A Airborne remote sensing in precision viticolture: assessment of quality and quantity vineyard production using multispectral imagery: a case study in Velletri, Rome surroundings (central Italy) [7472-47]

G. Tramontana, D. Papale, F. Girard, Univ. degli Studi della Tuscia (Italy); C. Belli, Terrasystem s.r.l. (Italy); P. Pietromarchi, D. Tiberi, M. C. Comandini, Consiglio per la Ricerca e la Sperimentazione in Agricoltura (Italy)

7472 1B Wheat growth modelling by a combination of a biophysical model approach and hyperspectral remote sensing data [7472-48]

N. M. Oppelt, Christian-Albrechts-Univ. Kiel (Germany)

\section{POSTER SESSION}

$747211 \quad$ Urban land cover changes assessment by satellite remote sensing imagery [7472-57] M. A. Zoran, National Institute of Research \& Development for Optoelectronics (Romania)

$74721 \mathrm{M}$ The application of unified surface water capacity method in drought remote sensing monitoring [7472-62]

$\mathrm{H}$. Zhang, Henan Institute of Meteorological Sciences (China) and Meteorological Bureau of XinXiang (China); H. Chen, Henan Institute of Meteorological Sciences (China); R. Sun, Beijing Normal Univ. (China); W. Yu, C. Zou, Henan Institute of Meteorological Sciences (China); S. Shen, Nanjing Univ. of Information Science and Technology (China) 
$74721 \mathrm{~N} \quad$ Monitoring drought dynamics in Huanghuai region of China using AVHRR-based vegetation health indices in comparison with ground data [7472-63]

M. Zhang, X. Zhu, J. Fan, G. Li, Y. Zhang, China Meteorological Administration (China)

747210 The application study of using temperature vegetation dryness index in regional drought monitoring [7472-64]

Y. Zhang, M. Zhang, X. Zhu, J. Fan, Y. Zhang, China Meteorological Administration (China)

$74721 \mathrm{P} \quad$ Agricultural drought monitoring, forecasting and loss assessment in China [7472-65] H. Chen, Henan Institute of Meteorological Sciences (China); H. Zhang, Henan Institute of Meteorological Sciences (China) and Xinxiang Meteorological Bureau of Henan (China); R. Liu, W. Yu, Henan Institute of Meteorological Sciences (China)

$74721 Q \quad$ The application of normalized multi-band drought index (NMDI) method in cropland drought monitoring [7472-66]

$\mathrm{H}$. Zhang, Henan Institute of Meteorological Sciences (China) and Meteorological Bureau of Xinxiang (China); H.-L. Chen, Henan Institute of Meteorological Sciences (China); S. Shen, Nanjing Univ. of Information Science and Technology (China)

$74721 \mathrm{~T}$ The optimal hyperspectral quantitative models for chlorophyll-a of chlorella vulgaris [7472-67]

Q. Cheng, X. Wu, Zhejiang Gongshang Univ. (China)

7472 is Study on the spectrum response of Cyanobacter to the $\mathrm{Pb}^{2+}$ pollution [7472-68] X. WU, Q. Cheng, Zhejiang Gongshang Univ. (China)

$74721 \mathrm{U}$ The spectral characteristics of Stellera chamaejasme L. with varied coverage in Qilian of China [7472-70]

H. Wang, J. Qian, M. Ma, X. Wang, Cold and Arid Regions Environmental and Engineering Research Institute (China)

747212 Complex microwave transmittivity of tree crowns [7472-77]

A. Chukhlantsev, S. Golovachev, V. Kobylianskij, S. Marechek, Yu. Tsargorodtsev, Institute of Radio Engineering and Electronics (Russian Federation)

747220 Assimilation of soil moisture in LPJ-DGVM [7472-78]

$X$. Wang, Cold and Arid Regions Environmental and Engineering Research Institute (China) and Graduate Univ. of Chinese Academy of Sciences (China); M. Ma, X. Han, Cold and Arid Regions Environmental and Engineering Research Institute (China); Y. Song, Cold and Arid Regions Environmental and Engineering Research Institute (China) and Graduate Univ. of Chinese Academy of Sciences (China)

747221 A real-time drought monitoring method: cropland soil moisture index (CSMI) and application [7472-79]

$\mathrm{H}$. Chen, Henan Institute of Meteorological Sciences (China); H. Zhang, Henan Institute of Meteorological Sciences (China), Meteorological Bureau of XinXiang (China), and Nanjing Univ. of Information Science and Technology (China); S. Shen, Nanjing Univ. of Information Science and Technology (China); W. Yu, C. Zou, Henan Institute of Meteorological Sciences (China) 
747222 Detection of vegetation LUE based on chlorophyll fluorescence separation algorithm from Fraunhofer line [7472-80]

L. Liu, B. Zhang, Ctr. for Earth Observation and Digital Earth (China)

747225 Critical analysis of empirical ground heat flux equations on a cereal field using micrometeorological data [7472-83]

C. Cammalleri, G. La Loggia, A. Maltese, Univ. degli Studi di Palermo (Italy)

747227 Monitoring winter-wheat phenology in North China using time-series MODIS EVI [7472-85]

M. Zhang, J. Fan, X. Zhu, G. Li, Y. Zhang, China Meteorological Administration (China)

747228 Disease detection in sugar beet fields: a multi-temporal and multi-sensoral approach on different scales [7472-86]

A.-K. Mahlein, C. Hillnhütter, T. Mewes, C. Scholz, U. Steiner, H.-W. Dehne, E.-C. Oerke, Univ. of Bonn (Germany)

747229 Evaluating crop land productivity using MODIS derived time serious vegetation index and water index in North China Plain [7472-87]

Z. Wang, Institute of Genetics and Developmental Biology (China) and Graduate Univ. of Chinese Academy of Sciences (China); Y. Shu, Univ. of Copenhagen (Denmark); S. Zhang, Institute of Genetics and Developmental Biology (China) and Graduate Univ. of Chinese Academy of Sciences (China); H. Li, Y. Lei, Institute of Genetics and Developmental Biology (China)

$74722 \mathrm{~A}$ Assessment of nitrate leaching on agriculture region using remote sensing and model [7472-88]

Y. Lei, Institute of Genetics and Developmental Biology (China); Z. Wang, Institute of Genetics and Developmental Biology (China) and Graduate Univ. of Chinese Academy of Sciences (China); H. Li, L. Zheng, Institute of Genetics and Developmental Biology (China); S. Zhang, Institute of Genetics and Developmental Biology (China) and Graduate Univ. of Chinese Academy of Sciences (China)

Author Index 


\title{
Conference Committee
}

\author{
Symposium Chairs
}

Steven P. Neeck, NASA Headquarters (United States)

Karin Stein, Forschungsgesellschaft für Angewandte Naturwissenschaften e.V. (Germany)

Conference Chairs

Christopher M. U. Neale, Utah State University (United States)

Antonino Maltese, Università degli Studi di Palermo (Italy)

Conference Cochairs

Katja Richter, Università degli Studi di Napoli Federico II (Italy)

Richard A. M. de Jeu, Vrije Universiteit Amsterdam (Netherlands)

Program Committee

Guido D'Urso, Università degli Studi di Napoli Federico II (Italy)

Manfred Owe, NASA Goddard Space Flight Ctr. (United States)

\section{Session Chairs}

$1 \quad$ Hydrological and Ecosystem Modeling

Antonino Maltese, Università degli Studi di Palermo (Italy)

2 Land Use and Change Detection

Christopher M. U. Neale, Utah State University (United States)

$3 \quad$ Irrigation Water Management

Katja Richter, Università degli Studi di Napoli Federico II (Italy)

$4 \quad$ Estimation of Vegetation Parameters

Antonino Maltese, Università degli Studi di Palermo (Italy)

$5 \quad$ Forestry and Coastal Applications

Christopher M. U. Neale, Utah State University (United States)

$6 \quad$ Lidar and Radar Applications in Hydrology

Richard A. M. de Jeu, Vrije Universiteit Amsterdam (Netherlands)

$7 \quad$ Thermal Infrared Remote Sensing

Antonino Maltese, Università degli Studi di Palermo (Italy) 
8 Energy Balance and Evapotranspiration

Antonino Maltese, Università degli Studi di Palermo (Italy)

9 Vegetation and Crop Monitoring I

Guido D'Urso, Università degli Studi di Napoli Federico II (Italy)

10 Vegetation and Crop Monitoring II

Christopher M. U. Neale, Utah State University (United States) 


\section{Introduction}

This proceedings volume contains papers presented during the conference on Remote Sensing for Agriculture, Ecosystems, and Hydrology XI. The conference was part of the $16^{\text {th }}$ International Symposium on Remote Sensing sponsored by SPIE. The symposium was held at the BCC Berliner Congress Centre, Berlin, Germany, August 31-September 3, 2009.

The conference is dedicated to providing rapid dissemination of scientific and technical information, and attracted scientists and professionals from throughout Europe, Africa, Asia, and the Americas. Approximately 50 oral and 25 poster presentations were given, covering a broad range of topics in the field of remote sensing applications in environmental science.

The program was organized according to major themes, with 10 sessions on Agriculture: Land Use and Change Detection, Vegetation and Crop Monitoring (2); Ecosystems: Forestry and Coastal Applications, Estimation of Vegetation Parameters; Hydrology: Hydrological and Ecosystem Modelling, Irrigation Water Management, Lidar and Radar Applications in Hydrology, Thermal Infrared Remote Sensing, Energy Balance and Evapotranspiration. The poster presentations also had good representation from the three major themes. The presentations described both fundamental and applications-based research activities from modelling, to laboratory and field experiments, to operational applications.

We extend our thanks to the session chairs (Katja Richter of Università degli Studi di Napoli and Richard A. M. de Jeu of Vrije Universiteit Amsterdam and Guido D'Urso of Università degli Studi di Napoli), and to the presenters for their efforts and to the participants for their insightful questions and discussions. Special thanks are also due to the host city for the excellent venue and to the SPIE organizational staff for their support prior to, during, and after the symposium. We look forward to an even more successful and exciting conference in 2010.

Christopher M. U. Neale Antonino Maltese 
Downloaded From: https://www.spiedigitallibrary.org/conference-proceedings-of-spie on 26 Apr 2023

Terms of Use: https://www.spiedigitallibrary.org/terms-of-use 